\title{
SHH Gene
}

National Cancer Institute

\section{Source}

National Cancer Institute. SHH Gene. NCI Thesaurus. Code C24810.

This gene is involved in signal transduction and neuronal development. 